\title{
Restoration after atrocities
}

\author{
Af Nils Christie
}

\begin{abstract}
What happened in Norway after the atrocities of July 22, 2011 is described as a long process of restoration. Not only of the victims, but also of the social system itself. Roses, not hatred dominated the first days after the occurrences. In the later court-case, the victims were given exceptional attention. Attempts to externalize the offender - create a picture of him as an insane evil monster - collapsed. He is one of us.
\end{abstract}

\section{Acts of horror}

It was in the afternoon July 22-2011. A huge bomb exploded in a car parked just outside the ministerial centre in Oslo. The centre is a tall building, with the prime ministers offices at the top. The building and the surrounding looked as war had hit. Eight people were immediately killed; more were in hospital, badly hurt. The offender, in his car filled to the brim with explosives, had been delayed in the traffic and the explosion occurred an hour after ordinary office hours. If in time hundreds would have been killed.

The first attempts to explain the atrocities followed immediately: May be some Muslim revenge for our participation in the wars in Afghanistan and Libya? Or for our reprinting of those caricatures of Mohammed? If so, bad times ahead for our immigrant population.

But then, as the night drew on, other alarming news dripped in: There were shootings at a summer-camp for politically active youth from the Labour Party. It took place on a tiny island in an inland lake an hours drive from Oslo. A tall man walking back and forth, systematically killing everyone he could find - some as young as fourteen. Without mercy, just killing any youth he saw. He saw many. 69 were murdered there. All in all, he killed 77 persons.

The horror, despair, and sorrow that spread in the country need an artist's hand to describe. I refrain, but point to one piece of news that brought some sort of relief during the long night. The offender was not an immigrant. He was a tall, blond man, clearly a Norwegian. And soon it became clear; this was the same man that some hours before had exploded the Governmental Centre. 


\section{Restoration, first chapter}

Are thoughts of restoration possible after such occurrences?

Those killed will never be back, - except in dreams and memories. And for those close to the killed ones, their opinion might be that the killer ought to burn in Hell, forever.

What is then left - to restore?

The social system is left.

\section{Roses, not hatred}

In the case of July 22, some elements in what can be seen as a restorative process started immediately. Soon after the bomb exploded, the Prime minister was on radio and television. His statements were those of sorrow and despair, solidarity with the victims, but also, central to his speech that night and the days and nights that followed; we will not meet these acts with vengeance and terror, but by preserving our ideals for a democratic society.

On the third day after the atrocities, a memorial meeting was held outside the City Hall of Oslo. The town has 600000 inhabitants. Estimates suggested that 150000 of us were there. The Crown prince spoke, the prime minister spoke, survivors spoke. I did not hear one sentence about revenge from any of them. Instead, as formulated by one of the survivors: Let us answer with roses, not with vengeance. Or, from another of the young survivors: If one man can expose so much hatred, imagine then how much love we can express together. The Mayor of Oslo put it like this in an interview: Together we will punish the killer. Our punishment will be more openness, more tolerance, more democracy. Some weeks after the massacre we had a municipal election in the country. The Mayor was re-elected with an extraordinary large margin.

Only roses, in words and reality. Nearly everyone had flowers in hand and left them later at several memorial points in town. A procession from the City Hall to the central church was planned, but cancelled. There were too many people, everywhere. Similar memorial ceremonies took place all over the country in the days that followed. Import tax on roses was temporarily removed to get sufficient supplies into the country. The public transportation system in Oslo had to be redirected not to destroy the monuments of flowers in the centre of town.

In a way, we came closer to each other these days. The politicians were an important part of this, and also driving forces. Our prime minister, Jens Stoltenberg, was quite extraordinary in his ability to bring words to feelings. Here was nothing of the political rhetoric of George Bush after September 11th or David Cameron after the youth riots in British towns. The political leaders of Norway 
agreed not to attack each other for a period, even though an election was close. The situation was too grave for party quibbling. The atmosphere during these last days of July reminded me of the days when the German occupation of Norway came to an end in 1945. An enormous feeling of community, a united nation. For a period.

Terrible days, but also with some hope. In an article with Hedda Giertsen two days after the atrocities, we used the title; $\gg$ A better Norway is growing out of this « (Informatíon, Copenhagen July 25, 2011). So it felt. The horror drove us to the streets, and there pulled us together.

What were we gathering around? First of all, the victims. Innocent youngsters had been together on that island to gain knowledge on how to preserve and improve our country. They were killed, without mercy. And then the system itself. We were all threatened. Basic values and perceptions of us as a nation had been under attack. The killer had challenged elements in our central value-system. International comparative studies show Norwegians to be at the very top in trusting each other and close to the bottom in killing each other. And then these atrocities!

\section{Restoring a country}

Norway was in these first weeks to some extent converted to one big arena of restoration. Usually, we think of restoration as a process going on between a limited number of participants; the victim, the offender, the mediator, - that is the prototype. But to us, in the days following July 22, the whole nation got involved. The shock and sorrow was so great that new forms had to be created. Emotions were displayed, values clarified, norms strengthened. To a large extent, the surviving youths from the island were the driving force in all this. No experts in between. Experts did not appear before the court-case was prepared. Roses, rather than hatred were these first days a gift to us all, directly from the surviving youths.

\section{But it was a penal court}

The court proceedings lasted ten weeks. It was a penal court. No other solution would have been possible. Even as an ardent believer in restorative justice - or in an alternative board for handling of conflicts, as I like to call these arrangements - I have to admit that I do not think it would have been a feasible alternative to handle a case like this outside the structure of the penal law. But much of what occurred in this court had strong similarities with what often happens in boards for alternative handlings of conflict. Much that went on in this court-caser ought to be crystalized, memorized, and used as models for how penal courts ought to 
operate in other, more usual cases. Elements of restorative justice ought to penetrate penal courts, not the other way around.

First and foremost, the atrocities of July 22 were not a case between a wrongdoer and a limited number of people. A whole nation was involved. It was a case of one person against most of society. We could not all be there. A suitable forum had to be found.

And that forum had to be an open forum. We all had the right to know. Most meetings of restorative justice take place in closed rooms without mediaattention. That is most often a necessity to assure free talk in that form of handling of conflicts. A penal court has to operate according to the opposite principle in an open society. And the court (Oslo tingrett) lived up to that expectation. Before the proceedings commenced, a 29 pages document was distributed. Here the principle and plans for the proceedings were outlined. Altogether, some 2500 persons would have the right to attend the case. 700 journalists from 200 different media-companies from all over the word had asked for accreditation. The interior of the courthouse in the centre of Oslo was re-arranged. The major courtroom here could now give space to 193 persons, - it was planned for daily attendance of some 100 persons close to the victims and 90 journalists. Others with rights to attend, and the remaining media had seven other courtrooms to their disposal in the building, and also rooms in a nearby hotel. These rooms were provided with large TV screens transmitting all that occurred in the major courtroom. In addition, 17 courts from North to South in the country were provided with the same equipment for those with the right to attend. Our National Broadcasting Company presented also most of what happened, in addition to numerous interviews and comments.

An additional reason for the impossibility of the use of alternative conflicthandling in this case, was that the culprit did not, and does not regret his acts. He stubbornly sees himself as a heroic soldier who had to do what he did. A martyr. He was engaged in a holy war. A saviour of the country and of Christianity from the invasion of Muslims, and also (what has received less attention) from cultural Marxism and feminism. He has spread a manuscript of more than 1500 pages with that message. He killed to rescue Norway. And Norway is not yet rescued, according to his standards. He fought a one-man war from the extreme right. $\mathrm{He}$ regrets nothing he says. Now he was demobilized. He could not be trusted outside. He was, and is, a dangerous man. In addition comes, that he probably soon would have been killed by someone if not protected by walls. 


\section{Roses in Courts}

But as it all developed, vital restorative ideals were cared for during the proceedings. The court became an arena for creating a national understanding of what had happened, a very efficient arena due to the exceptionally well-organized communication system from the courtroom to the rest of the population. The victims have been met with quite exceptional attention. The most moving example: Experts in forensic medicine explained what had caused the death in each individual case. It was all described in the most minute details Connected to each case, a large picture of the killed victim was exposed. After the doctors description of why and how death had occurred, a short memory speech was held, a speech describing the person as she or he had been in their short lives. After a week with the death, the next week gave room to survivors, many with visible marks from heavy wounds.

Never, ever, in modern times have so many victims been given so much attention in a Norwegian court. In addition came that the relatives of the killed as well as all survivors who so wanted were supported with one or several lawyers, a sort of assistant attorneys. More than 170 such assistant attorneys were engaged in the case. These assistant attorneys create some principle problems of balance in court. Most often they side with the prosecutors. It adds up to 172 prosecutors against two for defence.

In court the killer was mostly met with courtesy. He did wear ordinary civil cloths. His handcuffs were removed. He showed a sort of Nazi-greetings while entering the courtroom the first few days, but abandoned the praxis until leaving the court on the very last day. The prosecutor shook hand with him and he was examined without pronounced aggression. In a one-hour monologue he was allowed to explain the political ideas behind his acts.

The atmosphere in the court has been quiet, serious, - often desperately sad. A sort of funeral, day after day. With one exception. A man cried out; »Go to hell, you killer of my brother.« Then he threw one of his shoes in the direction of the killer. It was a symbolic act of denigration, - he was from Iraq. The shoe hit one of the defenders. Several in the room applauded. But a block away, I think it was the same day or the day before, some 40000 people had assembled on a huge square facing the building of our Labour party - on the initiative on some youngsters on face-book. Together they sang »Children of the rain-bow«, a song the killer had said he hated. It is a song for children of all colours. 


\section{On delivery of pain}

So far, so good, also in a restorative perspective. But it is in a penal court this takes place. It is a court to decide three elements:

If he is guilty?

If guilty, is he fit for punishment?

If fit for punishment; what is the suitable amount of pain he ought to receive?

As to guilt: He admits to the killings, but does not see himself as guilty. $\mathrm{He}$ sees himself as a commander in a holy war. A Christian soldier in war. So, here the court had, seemingly, an easy case. Guilty.

\section{Mad mans work?}

But then comes the next question in a penal court: May be this man is not an ordinary man? May be he is insane and can't be punished? To find out, experts on insanity were brought in.

Already before the court case opened, two forensic psychiatrists had investigated the mind of the killer. They declared him insane. Schizophrenic paranoia. A simple way to make him different from most of us. The whole report was supposed to be kept secret, but extensive leaks revealed that the psychiatrists, in addition to talks and tests, to a large extent based their diagnosis on his acts - the atrocities - without considering the political framework of it all. Acting like this, and writing about it as he had, to the forensic psychiatrists it became the final proof that he was insane.

The diagnosis raised a folk-storm. The victims - survivors and persons who had lost someone through his acts - asked for a new forensic observation. Prosecution protested, but the court accepted. A new pair of observers was called in. They declared him sane.

A baroque situation. The two pairs of forensic psychiatrists have through the ten weeks of proceedings been seated side by side on first row in the courtroom, facing the offender. The one pair seeing a man they have placed outside normality and therefore bound for mental hospital, the other pair facing a person they see as peculiar, but not more than that he is fit for punishment.

But this strange situation had a good side. The disagreement between the experts allowed the judges to regain control of what happened in court by revealing contradictions. Disagreement between experts made them vulnerable for critique and opened for sharp examination. Experts lost heir glory, the court could function as a court, and the judges were not only secretaries for the experts.

The court decided that he was sane, - to the great relief to many among us. A diagnosis of insanity would have been a helpful way to externalize him, convert 
him to a being different from most of us. But he is a Norwegian - like me. Same social class. For a time, I lived close to his neighbourhood. Why him? Where did he find his models, - and ideas? Or more threatening; is it something in being Norwegian that made this possible? We live in a culture pre-occupied with material success. And in a country quite recently engaged in several wars. When Norwegian pilots returned from Libya after what was supposed to be the successful bombing there, our minister of defence at the time received them with thanks for their accomplishments in bombing.

The more we make the man behind July 22 an evil, a monster, or an insane, the less we are able to understand the roots we have in common with him and also what we ought to change in the country if we want it restored to standards we can accept to live with.

A diagnosis of insanity would also have created another problem: Such a diagnosis hides the normality of killing. Relatively many are able to carry out the most awful of acts against other people; from electric shocks to torture to massextermination. They are not mad. They are ordinary, placed in situations that make these acts possible. It is not only a question of the banality of evil, but on understanding elements of how hell can be created as a matter of routine. Again we must ask; what is it with us, and also the global political situation, that makes such behaviour possible? How can we improve on the system to make killing less attractive? The challenge is to create social circumstances that make us all able to see the human being, - also in the killer.

\section{The sentence}

The court sentenced him to 21 years in preventive detention with a minimum time of ten years, and with an additional clause that would enable the state to keep him in prison for an unlimited amount of five-year periods if he still was considered dangerous. If not seen as dangerous, he will have to be released considerably earlier, may be after some 15 to 20 years.

Many, and particularly journalists from abroad (there were several hundred of them on the case) expressed surprise by what they found to be an extremely lenient sentence. But how could it have been more severe if we want to remain true to basic legal principles?

Lady Justice is most often presented with a sword in one hand and a scale in the other. The amount of punishment has to be balanced against the amount of evil acts committed. Not too much, not too little. But what then when the evil acts becomes overwhelmingly terrible? How then to create balance? 
How could the man who committed these atrocities ever pay back what he has done? Pay back in personal suffering? The man behind these killings belongs to the first division of evildoers in modern western history. Adolf Eichmann killed millions, but stood in some ways more distant from the concrete acts. Eichmann did it out of his office, an administrator of extermination. The man in Norway made and detonated the bomb himself. He then shot the teenagers on the island, moving around, slowly, systematically killing everyone he saw. He spared some small children. As he saw it, they were not dangerous. They had not yet been indoctrinated to accept Muslims to the country.

A punishment balancing the acts of the Norwegian killer is out of question. What he has done can never be paid back on him. Altogether he killed 77 persons. Should we bring him to the gallows 76 times, without hanging him, but let that happen on transport 77? A catastrophe has occurred, one that can only be met by adhering to the basic values of Norwegian society. Atrocities can never be balanced with the production of a similar amount of pain. We cannot answer atrocities with equal-to-equal. It has to be something less.

To find standards for this more limited answer, we must ask for help in oldfashioned values of forgiveness and grace. But to mobilize forgiveness and grace, one element is essential: We must come close enough to see him as more than a killer, we must be able to see him as a human being, simply as one of us.

\section{The killer as one of us}

This brings me to the core of what has been my personal as well as scientific interest throughout much of my life: The question about the conditions for, and consequences of coming close to others. So close, through life or art, that it becomes possible to recognize elements of common humanity in all sorts of people.

I believe that the more we are enabled to see each other as fellow human beings, the more we are controlled by that knowledge, and by the whole set of norms ingrained in us throughout life on how to behave towards people of all sorts, from babies to old folks. To see the other is to be captured in the web of norms that makes us human. The closer we come to another person, the stronger stand the inhibitions against handling that person in ways seen as unacceptable within the culture where we belong. To accomplish this is to me the great challenge for most sorts of crime-preventive work.

The killer himself wanted to be seen as something extraordinary. A commander in war. He wanted to wear a policeman's uniform on his first day in court when he was formally imprisoned. That was of course not accepted. He has been active as a body builder, and has also gone through surgery to look even more the 
perfect man. It is not particularly easy to see him as an ordinary human being, one of us.

\section{The end}

The judge read her verdict on August 24, 2012. No appeals followed, and on September 7 the sentence was legally valid. Never has the word »relief« been used more often « was the headline in Aftenposten, the largest newspaper in the country. Their editorial the day after the sentence had become legally valid had the title: »Clarification and relief «.

I think they captured the mood of the population. It is even confirmed by some research. For years, there have been international studies of the existence of trust in various countries. Norwegians seem to trust each other more than inhabitants in most other nations according to these studies, and even more so in the months just after the atrocities. Now we are back to normal, but still at the top. ${ }^{2}$ I think this has to do with that we live in welfare state, we are not so many, five millions, and we have - not yet, - created large internal class differences. We are still able to see each other.

But I fear the future. Money might be a killer of social cohesion. It is far from certain that our present oil-lubricated affluence will become a blessing for Norway. We all get more affluent, but the top level to an extent that threaten our up to now relatively egalitarian society. For a conference on crime prevention, I think it is of the greatest importance to warn against a development towards life forms where we loose each other as members of the same society.

\section{Noter}

1. Nils Christie er senior-professor, Institutt fir Kriminologi og rettssosiologi, Universitetet i Oslo.

2. Dag Wollebæk, Bernard Enjolras, Kari Steen-Johnsen og Guro Ødegård: Tillit i Norge etter 22 juli. Pp. 29-58 in:Helge Skirbekk og Harald Grimen: Tillit i Norge. Res Publica 2012. 